\title{
MÃOS NEGRAS, MENTES GREGAS: AS NARRATIVAS DE LUÍs dA CÂMARA CASCUdO SOBRE AS RELIGIÕES AFRO-BRASILEIRAS.
}

Durval Muniz de Albuquerque Júnior'

Resumo: O texto aborda o lugar dado ao negro e a contribuição africana para a história e a chamada cultura brasileira pelo erudito potiguar Luís da Câmara Cascudo. Tomando como objeto de análise seus escritos sobre a contribuição africana para a formação da sociedade brasileira, notadamente o livro Meleagro, procuramos analisar as imagens e os enunciados que, constantemente, estão associados ao negro e à cultura africana nas obras de Cascudo, como ele tende insistentemente em desafricanizar ou branquear a cultura brasileira, notadamente o que nomeia de cultura popular ou folclore. O texto tenta também entender o lugar de fala do erudito potiguar e o que o leva a ter esta visão sobre a participação dos africanos na constituição social do país e de seus costumes.

Palavras-chave: Afro-Brasileiros; Cultura Popular; Câmara Cascudo; Branqueamento. Desafricanização.

Abstract: The text talks about the position given to Afro-Brazilians and to the African contribution to Brazilian history and the so-called culture by the erudite Luís da Câmara Cascudo. The object of our analysis are his writings on the African contribution to the constitution of the Brazilian society, especially the book Meleagro. We try to examine the images and the statements that are constantly associated with Afro-Brazilians and the African culture in the works of Cascudo, as he tends, insistently, to deafricanize or whiten the Brazilian culture, especially what he calls popular culture or folklore. The text also tries to understand the opinion of the erudite from Rio Grande do Norte and what makes him have this view on the participation of Africans in the social constitution of the country and its habits.

Key-words: Afro-Brazilian; Popular culture; Câmara Cascudo; Whitening; Deafricanization.

\footnotetext{
' Universidade Federal do Rio Grande do Norte. E-mail: durvalal@uol.com.br
} 
Luís da Câmara Cascudo é um dos mais importantes intelectuais na formulação de metanarrativas da nacionalidade. Produzindo grande parte de sua extensa e significativa obra obedecendo aos ditames do dispositivo das nacionalidades e conforme as regras que instituíram a formação discursiva nacional-popular, que predominou, no Brasil, entre os anos vinte e os sessenta do século passado, o tema privilegiado de sua obra será o que nomeia de cultura brasileira. Estando entre aqueles que se dedicaram a fazer a narrativa da formação da nacionalidade brasileira, tomando, portanto, a história como o elemento através do qual interroga o que seria a constituição da cultura nacional em suas diferentes expressões regionais, em sua particular distribuição pelo território, em sua geografia, ${ }^{3}$ Cascudo é, no entanto, um autor que ainda faz por merecer maior atenção por parte daqueles que se dedicam a estudar os discursos que formularam identidades para a nação, que foram responsáveis pela instituição do imaginário que sustenta e significa a comunidade nacional brasileira.

Talvez por ter dedicado a maior parte de seus escritos a uma área de saber, a uma disciplina que foi historicamente alijada no país dos estudos universitários: o folclore - área que, quando tratada academicamente, como no estudo pioneiro de Florestan Fernandes, ${ }^{4}$ foi para denegar a sua cientificidade, para afirmar o direito de outras disciplinas como a antropologia, a etnografia e a sociologia de a substituírem nos estudos universitários - Cascudo ocupa este lugar marginal quando se trata de estudar os intérpretes do Brasil, injustiça que somente vem sendo corrigida recentemente, por exemplo, no campo da historiografia. ${ }^{5}$ No entanto, mesmo no interior do chamado Movimento Folclórico, que procurou, a partir dos anos quarenta do século XX, institucionalizar esta área de saber aproximando-a do Estado, articulando-a em instituições não-universitárias para compensar a rejeição da Universidade, instituições dependentes do mecenato dos poderes públicos, Luís da Câmara Cascudo vai ocupar um lugar de segundo plano, mesmo tendo sido dele a iniciativa pioneira neste processo de institucionalização e de aproximação do folclore das políticas culturais do Estado, com a criação, em 1941, da Sociedade Brasileira do Folclore, cuja sede era em sua própria casa, na cidade do Natal. Talvez por ter ficado em Natal, por não ter migrado para mais perto da sede do Estado brasileiro, a cidade do Rio de Janeiro, como fizeram Manuel Diegues Júnior, Afrânio Peixoto, Renato Almeida, que terão posições de destaque na criação do Conselho Nacional de Folclore por representar e estar ligado às elites de uma área periférica política e economicamente falando, o Mestre do folclore nacional, tal como foi monumentalizado ainda em vida, e sua 
obra tenham sido objeto, apenas, durante muito tempo, de obras de cunho panegírico de seus epígonos, discípulos, amigos e admiradores locais. ${ }^{6}$

No entanto, mesmo não tendo nem de longe a visibilidade e a centralidade que é conferida a Gilberto Freyre entre os chamados estudiosos do Brasil, podemos dizer que Luís da Câmara Cascudo foi o principal êmulo do sociólogo pernambucano. Podemos perceber na curta correspondência que trocaram, marcada sempre pela cortesia mas por longos e significativos períodos de silêncio, como, por exemplo, ao longo dos anos trinta, quando Câmara Cascudo torna-se um membro militante da Ação Integralista Brasileira e se aproxima do Estado Novo, enquanto Freyre amarga o exílio, mantém relações tensas com os intelectuais católicos que o acusam de imoral desde o lançamento de Casa Grande e Senzala e discorda abertamente do Estado Novo, notadamente do Interventor Agamenon Magalhães, nas vezes em que se referiram um ao outro, quase sempre elogiosamente, certa rivalidade intelectual. Uma espécie de disputa em torno do lugar de maior intelectual ou maior erudito do Nordeste. Creio ser bastante significativo o fato de que Câmara Cascudo tenha suprimido de seus relatos biográficos, escritos no final da vida, sua participação no Movimento Regionalista e Tradicionalista encabeçado por Gilberto Freyre, ocorrido justamente no período em que Cascudo cursava a Faculdade de Direito do Recife. ${ }^{78}$ Mesmo na correspondência que troca com Freyre só se refere a este fato uma única vez e ironicamente ao chamar o Centro Regionalista do Nordeste que, fundado pelo sociólogo pernambucano, encabeçara o Movimento de Centro Nacionalista do Recife, procurando, talvez, deixar clara uma diferença que o distanciaria de Freyre, o nacionalismo ao invés do regionalismo, uma fala feita em nome e para a construção da nação e não da região. ${ }^{9}$ Talvez tenha sido para marcar sua diferença em relação a Freyre que Câmara Cascudo tenha permitido que se cristalizasse uma dada narrativa de sua trajetória intelectual, uma dada versão de sua biografia, construída por um dos seus principais discípulos, o também folclorista Veríssimo de Melo, embora ela estivesse longe de ser lisonjeira para com ele e com o que produzira, que atribuía tudo aquilo que fizera no campo do folclore e da chamada cultura popular, o fato de ter deixado de lado a pretensão de ser historiador para se dedicar aos estudos folclóricos, a partir de 1939, ao recebimento do que Melo chamou de "a carta terrível” de Mário de Andrade, criticando tudo o que fizera até então e aconselhando-o a se dedicar ao estudo das coisas do povo de sua terra. ${ }^{10}$ Ter aceito, por muito tempo, esta versão para sua trajetória intelectual, que o vincula exclusivamente ao movimento modernista, do qual seria representante em Natal, e reduz o seu trabalho ao cumprimento de um mandato de Mário de Andrade, já que somente vai protestar contra isso indignado em entrevista nos seus últimos anos de vida, não por coincidência quando se reaproxima de Freyre, 
de quem recebe pessoalmente uma homenagem feita pela Fundação Joaquim Nabuco, criada pelo sociólogo de Apipucos, me parece ser mais um indício da disputa surda, da rivalidade nunca dita ou admitida que dividia os dois grandes nomes das letras no Nordeste.

Esta tensão entre os dois intelectuais, de renome nacional, que resolveram permanecer em seus Estados, periféricos tanto no plano econômico, quanto no plano político e cultural, assim como o fato de que Freyre tenha formulado o espaço regional, o Nordeste, como o espaço a partir do qual fala e a partir do qual trata da questão nacional e Cascudo tenha formulado o espaço nacional, o Brasil, como o espaço do qual fala, mesmo que seja a partir do Nordeste, designação espacial que aparece em sua obra a par com outras designações como o sertão, se deve também ao fato de que pertencem e representam parcelas distintas das elites nacionais. Enquanto Gilberto Freyre, ao formular a ideia de Nordeste ou mesmo ao escrever a saga da formação histórica da nação, dá a Pernambuco e, nele, as elites açucareiras da Zona da Mata daquele Estado, uma centralidade decisiva na história da civilização do país, colocando as chamadas províncias anexas desse Estado numa condição de coadjuvantes e auxiliares como se elas fossem meras extensões da história que se passava em terras pernambucanas, Luís da Câmara Cascudo como aquele intelectual que vai se colocar a tarefa de elaborar uma identidade para seu Estado, o Rio Grande do Norte, como o membro de maior destaque, audiência e capacidade de trabalho do Instituto Histórico e Geográfico potiguar, terá que fazer um esforço para diferenciar, para distinguir, para destacar o processo histórico ocorrido no Rio Grande do Norte, daquele ocorrido em Pernambuco. Ele terá que se dedicar a desanexar a história potiguar da história pernambucana, daí a ênfase que dará a vida sertaneja, ao sertão em detrimento do litoral e da Zona da Mata. Ao contar esta história; a constante afirmação da pouca expressão e importância do domínio holandês para a história do Rio Grande do Norte, ${ }^{11}$ seu caráter sanguinário e ruinoso em contraposição ao caráter construtivo e modernizador que este teria tido em Recife e em Pernambuco; destruir a mitologia holandesa, tão central na definição da identidade recifense e pernambucana, tornava-se uma tarefa fundamental para desligar a história do seu Estado da história do Estado de Freyre, que se não dedicara obra específica ao tema, estimulara e inspirara a que seu primo José Antônio Gonçalves de Mello ${ }^{12}$ escrevesse e publicasse a obra clássica sobre o tema, manancial de informações eruditas a alimentar a mitologia que sustenta a pernambucanidade.

Esta relação agônica entre o intelectual pernambucano de formação protestante, aluno do Colégio Americano Batista, e o intelectual potiguar de formação e militância católica, ligado ao Centro Dom Vital, talvez seja um elemento 
importante para entendermos o lugar que cada um dá a chamada contribuição do negro para a formação histórica, racial e cultural do Brasil e, mais especificamente, naquilo que interessa mais de perto a este texto, o lugar que cada um confere, a maneira como cada um trata, aborda, as religiões, as crenças e cultos afro-brasileiros. A obra primeira de Gilberto Freyre, Casa Grande e Senzala, ${ }^{13}$ dedica dois capítulos à contribuição africana para a formação histórica, social e cultural brasileira, fato inédito até então, o que confere de saída um caráter de novidade e de marco a esta obra, que rompe, em grande medida, com as explicações racialistas que predominava, até então entre aqueles que se dedicavam a interpretar a história brasileira. A afirmação da centralidade da contribuição africana para o entendimento do que seria o ethos, a singularidade, a autenticidade da cultura brasileira surge como uma tese revolucionária diante do que era a opinião dominante entre os letrados brasileiros. A promoção por Freyre dos primeiros Congressos Afro-Brasileiros, onde intelectuais de renome, autoridades e membros das elites políticas convivem, pela primeira vez, com pais-de-santo, mãesde-santo, brincantes de maracatu e capoeiristas, dá bem a dimensão da novidade da posição do intelectual pernambucano, vítima, por isso mesmo, de todo tipo de reproches e condenações por parte daqueles que defendiam a existência de uma hierarquia inata entre brancos e negros e a necessária observância da distância e da hierarquia entre as raças, embora, mais tarde, tornar-se-á contraditoriamente a vítima preferencial, talvez pela repercussão de sua obra e a assimilação social que teve muitas de suas assertivas da crítica levada a efeito pelo chamado Movimento Negro, pelos intelectuais negros, acusando-o de ser o teórico da democracia racial, assertiva que mascararia o preconceito racial no país, à medida que defendia a miscigenação, a mistura progressiva das raças, como um processo que democratizava as relações raciais e sociais e harmonizava os extremos raciais no país, estando o negro fadado a uma integração social pela via do branqueamento. Embora, por outro lado, não se possa deixar de pensar que há a possibilidade de se ler em Freyre certa defesa do que seria o necessário enegrecimento, a africanização do país, se não racialmente, pois esta hipótese estaria na contramão das teorias de base racial que circulavam no país e que foram formadoras de sua visão intelectual, mas do ponto de vista cultural, do ponto de vista dos costumes, com a africanização sendo uma forma de deseuropeizar o país e dar a ele a sua marca própria, como ele diz ter ocorrido com a língua portuguesa, amaciada, docilizada pelo uso africano.

A obra de Luís da Câmara Cascudo, suas leituras da história do Brasil, da formação histórica, social e cultural brasileira vai, justamente, na direção oposta daquela seguida por seu êmulo pernambucano. Se podemos localizar na obra de Freyre um claro desejo de valorização, de realce da contribuição dos africanos 
para a construção do povo e da cultura brasileiros, a obra de Câmara Cascudo vai ser marcada pela atitude de minimização, de redução, de limitação do que seria a contribuição dos negros africanos para a formação da sociedade e da cultura brasileira. Esta atitude se expressa através, por exemplo, desde a negação da presença física do contingente negro na constituição da população do seu Estado, o Rio Grande do Norte, ${ }^{14}$ até a constante negação de que seja de origem africana, dadas manifestações, dadas formas e matérias de expressão que comporiam a cultura, notadamente a cultura popular brasileira, à qual dedica grande parte de seus estudos. Em vários momentos de sua obra fica explícito o seu intento de desafricanizar a cultura brasileira, de afirmar a origem europeia, a origem branca ou, algumas vezes, asiáticas de dadas contribuições culturais que são atribuídas à contribuição africana. Muitos de seus estudos parecem movidos por esta intenção de negar a presença africana entre nós, mesmo naqueles em que, para surpresa do leitor, aparentemente se dedica a estudar um tema ligado à origem africana ou mesmo em livros onde a África e sua relação com o Brasil parecem ser o objeto central de seus estudos. ${ }^{15}$

Seu trabalho, assim como o de Gilberto Freyre, se articula a partir do topos historiográfico clássico, formulado desde o século XIX, do encontro das três raças formadoras e da análise da contribuição de cada uma no processo de formação da nacionalidade brasileira, considerando que seria através desta análise a melhor maneira de entender e escrever sobre o processo de construção da nação, do seu povo e de sua cultura. Câmara Cascudo, em seu livro clássico Literatura Oral no Brasil ${ }^{16}$ vai enunciar uma fórmula matemática que resumiria o percentual com que cada raça teria entrado na formação do povo e da cultura brasileiras: quando se analisava a formação cultural do país, chegava-se a conclusão de que a cada cinco elementos de contribuição branca correspondia três elementos de contribuição ameríndia ou ameraba, como gostava de escrever, e apenas uma contribuição dada pelos negros. Da mesma forma que, surpreendentemente, o vemos afirmar em seu Viajando o Sertão, que não encontrara praticamente um negro, ao percorrer, nos anos trinta, junto com o Interventor Mário Câmara, os sertões de seu Estado, onde a presença quilombola é ainda hoje um fato. Vamos nos surpreender ainda mais ao lermos um livro intitulado Made in África, fruto de uma viagem de pesquisa àquele continente, em busca de "elementos africanos que permanecem no Brasil” ${ }^{17}$ e encontrarmos a cada passo, a cada assunto de que trata, a cada verbete a denegação da origem africana do vocábulo, do costume, do ritual, da lenda. Como será costumeiro em sua obra, sua erudição clássica termina por recobrir os temas africanos que são, num primeiro momento, submetidos a um processo de analogia e assimilação a temas, matérias e formas de expressão de origem greco-romana, para em seguida se- 
rem remetidos em sua origem para a cultura clássica europeia, ou mesmo para antiguidades indo-europeias, desapossando, assim, os africanos de qualquer processo criativo próprio, de qualquer capacidade de criação autêntica. Em Made in África descobriremos, através das elucubrações eruditas do folclorista potiguar, que pouco do que julgamos africano lá se originou, que a maioria dos elementos culturais africanos que de lá foram trazidos para o Brasil, pelos negros, já seriam heranças do contato dos africanos com a Europa e com a Ásia, sendo que algumas práticas e crenças que julgamos africanas já teriam sua origem na própria América, já seriam fruto da transmigração de elementos culturais do Brasil para a África. Há em sua obra um explícito processo de branqueamento da cultura brasileira, contribuição decisiva para o modo como nos vemos do ponto de vista cultural. Cascudo merece ser estudado, dentre outros motivos, por ser um autor importante na formulação da ideia de cultura popular brasileira, na definição do que seria nosso folclore e, portanto, na formulação da identidade cultural da nação, do que somos como comunidade imaginada, para usar uma expressão de Benedict Anderson, ${ }^{18}$ e por formular uma leitura da história nacional que gira em torno da valorização da contribuição europeia, católica e sertaneja, mesmo chamando atenção, como faz Freyre, para as modificações, ampliações, assimilações que os elementos culturais europeus sofrerão no contato com um novo meio e no contato com as raças exóticas.

Para ilustrar este procedimento de branqueamento da cultura popular brasileira e este tendência cascudiana de remeter o popular, o brasileiro a origens que seriam clássicas, nos fazendo encontrar "o feitiço grego em mão africanas", em mãos negras, como diz logo na abertura de seu livro Meleagro, do qual trataremos, com mais vagar, ainda neste artigo, comentarei um dos capítulos do livro Superstição no Brasil, intitulado "O barrete do saci". Ele inicia o verbete se referindo a inquérito feito, em 1917, pelo jornal Estado de São Paulo sobre o lendário personagem popular Saci Pererê, que é descrito como sendo um pretinho, com um só olho e uma só perna, atrapalhando todas as coisas vivas, assobiando e assombrando. Um traço característico deste personagem seria o uso no cimo de sua "cabecinha irriquieta" de uma carapuça vermelha, da qual viria todos os seus poderes mágicos, inclusive o seu poder de encantamento. Quem se apoderasse desta carapuça teria o controle sobre o saci, podendo pedir-lhe o que quisesse: riqueza, poderio, grandeza. Cascudo então procede à primeira aproximação do saci com outros personagens lendários, de origem portuguesa, que apresentariam o mesmo tipo de cobertura, o Fradinho da Mão Furada e o Pesadelo, que também possuíam em comum com o saci o fato de terem a mão furada. Desta primeira analogia salta então para uma generalização: "Carapuças que dão invisibilidade são comuns nos contos europeus”. Seguindo uma trajetória que 
é comum nos processos de analogia presentes em suas obras, do Brasil chega-se a Portugal, daí ao restante da Europa, terminando por chegar à Grécia antiga, onde vai encontrar o personagem Perseu usando um elmo que o tornou invisível aos olhos das Górgonas. Só que dos exemplos que cita, retirados de autores como José Leite de Vasconcelos e Saintyves, a referência à carapuça para nomear o costume usado na cabeça pelo personagem lendário, só ocorre no caso do Pesadelo: o Fradinho de Mão Furada usa um barrete e o personagem grego Perseu usa um elmo, mas a diferença de nomes que têm os objetos não parece ser um obstáculo para o desejo de encontrar semelhanças através dos tempos e das culturas, que não é um procedimento específico de Cascudo, mas comum a toda tradição dos estudos folclóricos e etnográficos: a busca de constantes e permanências, em detrimento das diferenças e mudanças. Continua, então, em busca de figuras similares: o Pretinho do Barrete Encarnado de Portugal, o gorro colorado ou o Carapuça Vermelha, nomes do diabo na Espanha e em Portugal. O pretinho saci, uma entidade mágica da floresta brasileira, começa assim a ser aproximado do diabólico. Será pelo fato de que no imaginário racista e cristão europeu, no qual foi formado o folclorista potiguar, o diabo seja preto? Em seguida, lembrando das fontes clássicas que sempre foram a chave para suas interpretações do popular brasileiro e nordestino, se refere aos íncubos romanos, certos fantasmas opressores, que apareciam com carapuças vermelhas na cabeça, que se fossem arrebatadas dariam riqueza a seu possuidor, referidos no Satyricon de Petrônio. O chapéu do íncubo era o Pileum ou Pileus, carapuça de forma oblonga, de cor vermelha, muito popular em Roma, onde seria um símbolo de liberdade, do qual teria se originado o barrete frígio, imagem da liberdade individual e coletiva, materialização do governo republicano. Diz Cascudo, então, que o Pileus posto na cabeça de um escravo significava sua liberdade, sua alforria: o Pileus seria, assim, sinônimo de manumissão. ${ }^{19}$ Neste passo, se encaminha para a conclusão do verbete fazendo a seguinte afirmação peremptória:

A carapuça do Saci Pererê é justamente o Pileu romano. Significaria que o pretinho é livre para importunar a paciência alheia e ligado a ideia de encantamento, da força misteriosa dos talismãs. Converge ainda a cor vermelha, sugestionadora e com séculos de significação sagrada. ${ }^{20}$

Mas haveria outra possibilidade de interpretação, haveria outra tradição a que poderia ser associado o uso da carapuça vermelha pelo Saci, além daquela do Pileu romano, do negrinho-do-barrete-vermelho portuguesa, da sinonímia infernal do gorro vermelho peninsular, do ciclo do chapéu mágico europeu, uma tradição africana, a imagem de um "fez" ${ }^{21}$ vermelho, de um gorro feito com toalhas vermelhas enroladas em rodilha, usados pelos negros africanos, mas Cascu- 
do aventa esta hipótese apenas para rapidamente negar esta possibilidade e afirmar categoricamente que nenhum escravo trouxe tal tradição para o Brasil. ${ }^{22}$ Negada a possível origem africana do uso da carapuça pelo negrinho lendário brasileiro, termina o texto com esta exultante conclusão:

O chapéu do Saci Pererê é o Pileus, europeu e molhado com as águas da feitiçaria, da bruxaria, da superstição romana, espalhada por este mundo de meu Deus $[\ldots]^{23}$

O mundo dos deuses africanos também será visitado pela curiosidade etnográfica de Luís da Câmara Cascudo. Os cultos, crenças e rituais africanos ou atribuídos a origens afro-brasileiras serão por ele tratados em suas obras, sem, contudo, esquecer de seu Deus, o dono de seu mundo, devoção e imagem do divino que em muito influenciará no tipo de tratamento, na abordagem que confere às práticas e crenças religiosas que teriam matrizes africanas. Câmara Cascudo era um homem religioso, um intelectual católico, não apenas na vida privada, mas em sua militância pública. Tal traço biográfico é relevante para entendermos dadas posições que irá adotar em relação aos cultos africanos, reforçando ou contribuindo para a formação de sua mirada branqueadora, etnocêntrica, que conviverá, em tensão, com a sua curiosidade, com sua vontade de saber, com sua simpatia pelas manifestações culturais das camadas populares, dos mestiços, indígenas e negros. Para tratarmos das narrativas sobre as religiões afro-brasileiras, presentes nas obras de Câmara Cascudo, vou tomar como objeto de análise o livro que publicou em 1951 sobre o catimbó, culto religioso de caráter popular, vítima, na época, de intensa perseguição policial, que estuda a partir de sua presença na cidade do Natal, contagiado, desde o final dos anos vinte do século passado, "pelas reportagens de João do Rio às religiões suplementares na Capital Federal.” Quando Mário de Andrade se hospeda em sua casa em 1928, teve o "corpo fechado" por um Mestre catimbozeiro que freqüentava a chácara onde Cascudo morava, no bairro do Tirol, a quem o intelectual paulista pagou vinte mil réis. ${ }^{24}$ Este livro é exemplar de todas as ambiguidades e contradições que podemos notar em muitas obras do autor potiguar, com ênfase nesta empresa de desafricanização da cultura brasileira, em seu processo de branqueamento, acompanhada, ao mesmo tempo, de curiosidade simpatia e respeito pelas manifestações culturais populares.

Esta sistemática negação do que seriam as contribuições africanas para a cultura brasileira é indiciada, no caso deste livro dedicado a fazer uma etnografia do catimbó, logo de saída, pelo próprio título que escolhe para a obra: Meleagro: pesquisa do Catimbó e notas da magia branca no Brasil. Meleagro, que ele próprio admite ser "nome pedante”, personagem lendário da Grécia antiga, teria 
sido um príncipe etólio que, ao nascer, viu sua vida ligada a um tição que ardia na lareira. Altéia, sua mãe, guardou com cuidado a acha ardente que escondia a existência do filho e que o tornava invulnerável, insensível e imortal. Este herói acompanhou Jasão na conquista do Velocino de Ouro e matou o javali gigantesco que Minerva mandara para devastar as terras de Calidon. Atalanta, princesa da Arcádia, dera o primeiro golpe e o príncipe etólio lhe ofereceu a cabeça do monstro, sob protesto de Plexipo e Toxeu, tios maternos a quem Meleagro mata com sua lança. Altéia, sabendo da morte dos irmãos, enfurecida atira ao fogo o tição que era a vida do filho, quando este se consome, Meleagro morre. ${ }^{25}$ Mas que relação teria este mito grego com a religião de predileção de homens e mulheres pardos e pretos, "vivendo em casinhas de palha, de taipa oscilante, fugindo, tremendo das visitas policiais, arrastados como bichos curiosos diante das máquinas fotográficas para a identificação criminal e jamais atendendo curiosidade elegante e jornalística”, ${ }^{26}$ como ele mesmo descreve? Se ele próprio diz que os mais antigos mestres de catimbó foram negros e ainda seriam, na maioria absoluta, mestiços e mulatos; se algumas entidades presentes no catimbó, como o Pai Joaquim, são figuras de pretos velhos desaparecidos, por que associar o catimbó a um mito grego ${ }^{27}$ Embora diga ser o catimbó o maior exemplo dos processos de convergência afro-branco-ameríndia, "as três águas descendo para uma vertente comum, inseparáveis em sua corrida para o Mar”, ${ }^{28}$ nomeia o livro de Meleagro, pois, a tese que defende ao longo do livro é de que o catimbó, embora seja, como todos os cultos, a soma de diversas influências, "a feição mais decisiva” seria dada "pela feitiçaria européia, o 'mestre’ e seu prestígio, a consulta sem obrigação de adesão”. "Ausência de iniciação, reuniões festivas, aprendizado ostensivo e sistemático". ${ }^{29}$ Nomeia o livro de Meleagro pois a magia que vive no catimbó seria a mesma que matou o herói grego..$^{30}$ Ou seja, o catimbó, como tantas vezes ocorre na obra de Cascudo, embora seja fruto de contribuições africanas e indígenas, termina por ser "uma constante etnográfica de surpreendente poderio psicológico" ${ }^{11}$ que nos leva aos gregos, seria "feitiço da Grécia, em mão africana”, 32 magia branca em mãos negras.

Embora se refira à contribuição indígena presente no uso de dadas plantas no ritual do catimbó, figurada no tuxaua cheio de mistérios, ensinando remédios ou indo flechar os inimigos com flechas invisíveis e mortais e a contribuição negra figurada por “seus 'mestres' que seriam todos catimbozeiros mortos, exescravos - generalização a que ele próprio vai fazer inúmeras restrições ao longo do texto - vidas sem história, tornados soberanos nos reinos do Vajucá e de Juremal”, ${ }^{33}$ seria a contribuição europeia, a bruxaria de gregos e romanos, "processos perpétuos de encantamento" - a negação da historicidade, a construção de uma espécie de temporalidade mítica, também é uma constante em Cascudo - 
revividos nas rezas católicas usadas pelos portugueses e pelo preto fiel a Xangô o que definiria a singularidade do catimbó. ${ }^{34}$ Nesta empresa de busca das origens do catimbó, embora reconheça que tudo está "escuro, misturado, confuso", ${ }^{35}$ que o catimbó reúne "na sua união como num mesmo bloco de mármore, as participações de brancos, negros, ameríndios", ${ }^{36}$ não deixa de tentar deslindar seus elementos constituintes e em um exercício de pura imaginação, em que a vontade de atribuir a origens europeias as práticas catimbozeiras, traça o que seria a provável trajetória que teria levado elementos da bruxaria greco-romana a chegar até o Brasil. Mesmo afirmando que a bruxa europeia não recebia espíritos de outro mundo, espíritos orientadores, como ocorria com os mestres do catimbó, apenas ouvindo consultas, aconselhando, receitando, elaborando filtros e poções; mesmo reconhecendo que era nas religiões negras e indígenas que os deuses falam pela boca de sacerdotes; alegando não haver documentação de época sobre este tema referente à África quinhentista, num exercício de pura imaginação voluntarista levanta a hipótese de haver uma influência europeia em solo africano "já que o pé europeu batia areia do setentrião africano desde tempo velho imemorial” - a precisão temporal e a sustentação de suas hipóteses através de documentos é uma regra da ciência moderna nem sempre observada por Cascudo -. Através da pura suposição e de uma série de indagações meramente retóricas como: até onde influiu o árabe? Até onde espalhou o branco a semente de sua projeção? Até onde desceu o romano ${ }^{37}$ Cascudo vai dirigindo o leitor no sentido de aceitar sua tese da origem europeia do catimbó, tese que parece ser um parti-pris, que parece não ser formulada a partir da documentação, mas um pressuposto apenas a ser demonstrado retoricamente, mesmo que para isso deva-se dar liberdade à imaginação e fazer muita ginástica mental. Ele mesmo chega a dizer que "há muita afirmação que é intuição ou intenção", ${ }^{88}$ - talvez um ato falho, freudianamente falando. Creio que em Cascudo há muita intuição que é intenção, há muita afirmação que nasce apenas de sua vontade. Ele manipula o material de modo a sustentar as suas teses que vão sempre no sentido de desapossar os africanos da iniciativa de qualquer de suas matérias e formas de expressão culturais. O que mais chama atenção nas perguntas retóricas acima, embora o próprio Cascudo saiba que os hominídeos, segundo as teorias aceitas hoje, surgiram na África, é que em nenhum momento elas permitem supor que possam ter sido os próprios africanos a estarem na origem de seus elementos culturais, se não foram os europeus, em algum momento remoto da história, que os criaram, foram os árabes. ${ }^{3940} \mathrm{O}$ que fica implícito é que nunca se pode supor que tenha sido os próprios povos africanos os autores de suas crenças. Para asseverar isso lembra ainda que na literatura oral, muitas vezes o que se pensava ser um precioso conto africano trazido para a Europa por viajante europeu, era na verdade uma fábula 
de Esopo ou "um episódio do Romance da Raposa, que toda Europa sabe dormindo contar e repetir". ${ }^{41}$

Apesar de, em dado momento do livro, relatar a importância que tem para o catimbó natalense os contatos que seus mestres mantêm com os Estados do Pará e do Amazonas, a que chama, inclusive, de "Universidades do curso secreto", onde mestres nordestinos, após juntarem dinheiro, iam passar uns meses estudando, acompanhando "um short course" e de informar "em segredo para a Polícia não saber" - estranho segredo mantido pelo registro em um livro, para o qual muito contribuiu a própria polícia, como ainda veremos neste texto - que os mestres da Pajelança paraense, alguns de fama, visitavam constantemente as capitais nordestinas, tendo um deles estado em Natal com passagens pagas e gratificação de Cr\$ $10.000,00,{ }^{42}$ vai afirmar que a Pajelança indígena não está na origem do catimbó,${ }^{43}$ sem que apresente nenhuma evidência para sustentar a sua tese - muitas vezes a impressão que se tem é que, como se tornou um mestre respeitado no campo de estudos do folclore, basta a sua palavra para algo se tornar aceito, se tornar verdade, sem que precise apresentar quaisquer indícios ou documentação para apoiar o que diz, mesmo num caso como este em que os indícios, que ele mesmo aponta, parecem se dirigir no sentido contrário do que assegura -. Diz que entre o catimbó e a Pajelança há intercomunicação, do que apresenta elementos de comprovação, mas não dependência ou filiação, opinião que não só não é sustentada por nenhum elemento ou argumento de prova, como seus relatos nos permitem duvidar de tal assertiva, pois ele próprio diz que "os Pajés vêm, trabalham e deixam alguma técnica nas mãos dos mestres catimbozeiros locais”, ${ }^{44}$ embora tenha afirmado antes que a ciência do pajé americano ou do Quimbanda de Angola não seria um elemento decisivo para o catimbó. ${ }^{45}$ Não existiria dependência entre cultos que, como ele mesmo informa, trocam entre si materiais usados nos rituais, como a jurema, levada do Nordeste para a Pajelança amazônica e o tauari, a piripirioca, as raízes, as resinas, as folhas usadas pelos catimbós nordestinos trazidos da Amazônia? ${ }^{46}$ Trata-se, pois, de afastar a possibilidade de que o catimbó tenha como origem principal outra que não a cultura europeia. Composto pela parte "não-oficial, não-ritualística das religiões negras, americanas e européias”, condenado pelos Concílios da Igreja Católica, pelas instruções policiais, desprezado por Pais-de-Terreiro e Mães-de-Santo, o catimbó, conclui ele, “é bruxaria sem recorrer ao diabolismo medieval”, é “culto irregular e maldito, sem ligação e coerência, sem hierarquia e gradações, vivendo pela exploração do Medo, origem dos deuses pretonianos”. ${ }^{47} \mathrm{E}$ assim, após um verdadeiro tour de force, voltamos à antiguidade clássica, reencontramos na origem do catimbó os deuses de Petrônio, o escritor satírico da corte de Nero. No princípio, sempre, Grécia e Roma. 
O processo de desafricanização do catimbó e a recusa cascudiana em relação aos cultos africanos vão quedar patentes na maneira como ele trata as relações, as diferenças e semelhanças entre o catimbó e as duas outras religiões de origem africana: a umbanda e o candomblé. Logo no preâmbulo que escreveu para a segunda edição da obra, em 1978, vinte e seis anos depois da primeira edição, Câmara Cascudo vai tratar de diferenciar o catimbó da umbanda que, segundo ele, mesmo em Salvador quando fora "garboso calouro" da Faculdade de Medicina da Bahia, dela ainda não ouvira falar de sua existência, pelos idos de 1918. Em 1948, Édison Carneiro não registrara o vocábulo em seu livro Candomblé da Bahia. Somente nos anos sessenta do século passado é que a umbanda chegara a Natal, tendo um espantoso crescimento, contando com cerca de 400 terreiros naqueles anos em que escrevia o texto. Contando com entidades organizadas de coordenação, a União Espírita de Umbanda e a Federação de Umbanda, que chegavam a distribuir convites impressos para o ritual de oferenda de presentes a Iemanjá, realizado na Praia do Meio, na última noite do ano. Ritual do qual Cascudo logo encontra, no mundo clássico europeu, a sua origem: "a oferenda a Ino Leucotéia, protetora dos portos, com santuário em Epidauro Limera, Lacônia, Grécia, com a resposta afirmativa se mergulhasse a oferta”. ${ }^{48}$ Tendo sido formado na tradição clássica europeia, tendo lido, ainda muito jovem, a toda literatura greco-romana, conhecendo muito pouco as culturas africanas, Cascudo tende a projetar sobre toda e qualquer prática ou crença africana à sombra da similitude com práticas e crenças dos povos da antiguidade da Europa. Não só o catimbó, mas, já na primeira referência aos rituais da umbanda, estes aparecem como práticas feitas por mãos negras, mas pensadas por mentes gregas.

No capítulo intitulado "Que é Catimbó? Nome e Função" ${ }^{49}$ logo vai dizer que o catimbó difere dos candomblés da Bahia e das macumbas do Rio de Janeiro. O catimbó é tratado, em dados momentos do livro, como estando num nível inferior na hierarquia das crenças em relação às duas congêneres africanas. Cascudo diz que um Pai-de-Terreiro que se preze não chamaria um mestre do catimbó de colega, nem mesmo o veria com a tolerância de quem exerce uma atividade paralela, pois existiria, entre os dois, a distância equivalente aquela entre um chofer de caminhão e um piloto de avião. ${ }^{50} \mathrm{O}$ catimbó seria clandestino, humilde, de existência secular - Cascudo adora tornar as coisas seculares -. Ao contrário da macumba e do candomblé, não haveria no catimbó “indumentária bonita, bailado cutucando os nervos, negras balançando na cadência entorpecedora dos atabaques", não haveria "sonoros de danças, músicas, festas de iniciação atraindo o povo e ampliando prestígio, levando suas melodias e ritmos aos microfones, seus babalorixás dando conversa nos jornais, com fotografias nas revistas e livros", no entanto o velho catimbó - o que faz supor que, para Cascu- 
do, o catimbó antecederia estas outras práticas religiosas - não recuaria. ${ }^{51} \mathrm{O}$ transe ou a possessão, que no catimbó chamar-se-ia de acostamento, não teria a mesma dramaticidade dos candomblés e das macumbas. Cascudo diz que, nas vezes em que frequentou as sessões de catimbó, por curiosidade etnográfica, evidentemente, nunca testemunhou cenas comparáveis às das filhas-de-santo desmaiando, se estorcendo, com explosões de movimentos sacudidos ou ficando estáticas, fazendo caretas, roncando. “O 'cair no santo', com suas convulsões ou imobilidades impressionantes, está bem longe do cerimonial de um 'mestre' na visita cordial a um Catimbó nordestino”, ${ }^{5253}$ diz ele.

Ao mesmo tempo em que busca desfazer certos preconceitos em relação ao catimbó e seus mestres, os catimbozeiros, designação, que reconhece, tornouse difamatória, vai reproduzir outros tantos, notadamente em relação aos que seriam os cultos similares e concorrentes: a macumba e o candomblé. Procura desmentir a fama de sujos, beberrões e desonestos que acompanhava os mestres do catimbó. Para ele, o catimbozeiro sujo, com vício de bebida, repugnante, não sustentaria mesa nem clientela. Para atestar o que diz, adota um procedimento constante em suas obras, apela para o testemunho de caráter pessoal ou biográfico:

João Germano das Neves, Mestre Germano, o devoto de Xaramundi, freqüentava minha casa e ninguém o identificou como catimbozeiro. Decente, colarinho e gravata, sapato asseado, sustentava conversa e todos o tinham por um pequeno comerciante ou proprietário de estábulo. ${ }^{54}$

Da mesma forma diz que um mestre de catimbó ladrão, recebendo dinheiro e não fazendo o trabalho, seria cognominado de porco e poucos o procurariam, a não ser aqueles clientes com predileção pelo errado. ${ }^{55}$ Embora algumas mulheres exercessem a função de mestre no catimbó, dirigindo o que ele chega a chamar de "grotesco cerimonial", ${ }^{56}$ elas eram em bem menor número que os homens. A maioria dos mestres contaria com mais de cinquenta anos, sendo raro o mestre jovem. ${ }^{57}$ Distingue, então, de forma bastante preconceituosa, o mestre do catimbó do pai-de-santo da macumba ou do candomblé:

Ao contrário do pai-de-santo pederasta, imitando mulheres, o 'mestre' faz uma questão severa de manter 'respeito de homem’. Fala-se, naturalmente, do Catimbó tradicional, sem as extremas de miséria, evidenciando a precariedade da profissão. Um mestre abastardado, somítico, gatuno, bêbado, sujo, não merece consultas nem terá ‘poderes' e ‘saberes’ justificadores de uma 'mesa’ concorrida. Esses elementos não anulam um babalorixá porque há, em redor, o corpo fiel das filhas-desanto, sustentando o culto do orixá, apesar da ignomínia do 
seu ministro. A conduta do 'mestre' no Catimbó exige, pela sua função individual e sem complexo ritualístico num séquito devoto, atenção maior. ${ }^{58}$

Ofuscado pelo candomblé e pela macumba, o catimbó residiria no meio dos mocambos pernambucanos, baianos, cariocas, vivendo do prestígio de seus mestres entre a população do lugar. ${ }^{59}$ Para Cascudo, o catimbó não era uma religião, não havia liturgia, promessas, votos, unidade de protocolo sagrado, seria um consultório tendendo para a simplificação ritual. Ao contrário da macumba e do candomblé não haveria festas votivas, nem cerimoniais coletivos. Diz ele:

Não há corpo de Filha-de-Santo para louvor divino dos Orixás nem preparação obediente das moças iauôs. Nem instrumentos musicais resistiram à dissolução, se é que houve. Resta a 'marca-mestra', cabacinho na ponta de uma vareta, com que o mestre divide o compasso das 'linhas'. Nem cores, vestidos, contas, enfeites especiais. Nem alimentos privativos, fetiches de representação, iniciação para os Babalaôs, Pai-de-Terreiro, Babalorixá. Catimbó não é Macumba nem Candomblé. ${ }^{60}$

Adotando acriticamente a racista e preconceituosa divisão entre magia branca e magia negra, classificações hierárquicas como alto e baixo espiritismo, entre trabalhos para as direitas e trabalho para as esquerdas (que seria presente no próprio catimbó), que repercutem dadas formas de distinção, de desclassificação e de exclusão no interior da sociedade brasileira, Câmara Cascudo vai procurar pensar e definir as práticas presentes no catimbó a partir delas. Se a divisão entre trabalhos para as direitas e trabalhos para as esquerdas seria um código interno à realidade com que trabalha, as outras categorias são exógenas, pertencem à cultura hegemônica, são estranhas ao universo cultural do catimbó, representam um olhar e valores do mundo culto e branco que o autor representa. Embora tenha simpatia pelo culto humilde, mesmo que tenha até se utilizado de sua condição de advogado para defender alguns praticantes, junto aos delegados de polícia, conseguindo com isso a simpatia e a disponibilidade dos mestres para lhe revelar certos segredos do ritual catimbozeiro, Cascudo adota em seu ensaio um conjunto de categorias e conceitos que tende a desqualificar o objeto de sua pesquisa. Categorias e conceitos que, no entanto, não chegam a ser tão pejorativos quanto aqueles usadas pelo prefaciador da obra, o médico Antônio da Silva Mello. Ficamos nos perguntando, ao lermos o prefácio, sabendo da função que ele tem: texto que vem no início, que antecede a obra para apresentá-la, para recomendá-la, para legitimá-la e, de certa forma orientar, a sua leitura, se Câmara Cascudo concordava com as ideias expostas por seu prefaciador, se ele via na sua obra a mesma utilidade defendida pelo médico mineiro. Alguém escolhe um 
prefaciador e publica um prefácio sem concordar com o que dizem? Cascudo não teria percebido a contradição entre o que o prefaciador diz e o fato de ter dedicado seu tempo de estudo ao catimbó, ou ele também partilhava da visão de Silva Mello, que valoriza seu trabalho nestes termos:

São observações desta natureza que precisam tornar-se melhor conhecidas e ser divulgadas, pois somente assim poderemos nos libertar desse extraordinário acervo de ignorância e exploração, que tanto tem entravado o progresso da civilização. Vivemos ainda em pleno período da magia, quando já devia estar ela, de há muito, na pré-história, entre os elementos mis vetustos da arqueologia. (grifos nossos) ${ }^{61}$

Ele nomeia o livro de Meleagro justamente por considerar que o catimbó seria uma manifestação da magia branca de raízes europeias. Operaria no catimbó a mesma lei da contiguidade simpática, que teria sido enunciada por Huber e Mauss, presente na feitiçaria que seria, para Cascudo, "pai e mãe do Catimbó". Segundo esta lei o que pertenceu ao todo continua a ele ligado idealmente mesmo depois da separação. Por isto o uso de partes do corpo da pessoa, como cabelos, unhas, saliva, sangue, esperma, dente, suor, urina, roupa, que se quer atingir com o trabalho, com a coisa-feita, com o ebó, com a muamba, com o canjerê, com a mandinga - sucessão de palavras africanas a denunciar a procedência destas práticas que, no entanto, são remetidas por Cascudo à feitiçaria europeia. Operando com a ideia positivista de lei Câmara Cascudo enuncia, ainda, que o catimbó obedece à lei que o efeito é semelhante à causa que o produziu: imitando-se 0 fenômeno, reproduz-se a causa originária. No catimbó estaria presente a simpatia, que Frazer teria nomeado de magia imitativa. Estas duas leis, operando em conjunto no catimbó, justificariam o uso da técnica da transferência, do transporte, do transplante, ou seja, seria possível transmitir sofrimentos físicos e morais aos vegetais, aos minerais e aos animais. Um objeto podendo guardar o segredo alheio e mesmo a vida humana ${ }^{62} \mathrm{E}$ conclui Cascudo:

Toda ciência feiticeira, toda essência do Catimbó reside nesses princípios. Fixar a vida, transferi-la, completa ou parcial, para um objeto, torná-lo a representação integral da sensibilidade, da vontade humana, comandada, dirigida, anulada pelo 'mestre de mesa', feiticeiro, 'mestre’ do Catimbó, é a essência, fim, realidade. ${ }^{63}$

Além da pretensão de ter encontrado a essência, o fim, a realidade do fenômeno social ou cultural que analisa, que é uma marca da obra de Cascudo, esta citação explicita mais um artifício retórico usado pelo autor para europeizar o catimbó, a aproximação questionável entre a figura do mestre catimbozeiro - 
expressão que aparece sempre entre aspas no livro, não sabemos se por ser uma expressão nativa ou por que o autor busca assim relativizar a ideia de que sejam mestres - e a figura do feiticeiro, figura de origem européia e que mobiliza um imaginário bastante pejorativo, criado por toda a perseguição da Igreja Católica e os discursos diabolizantes cristãos. A visão negativa do catimbó se aprofunda quando Cascudo o nomeia de uma expressão do baixo espiritismo, contrapondoo ao que seria o alto espiritismo dos seguidores de Allan Kardec. ${ }^{64}$ No entanto, em dado momento do livro, contrariando inclusive sua tendência a tratar as manifestações culturais populares como se fossem sobrevivências de outros tempos, como se não tivessem historicidade, se refere ao fato de que, nos anos setenta, o catimbó estaria assimilando algumas práticas e alguns aspectos do culto espírita kardecista. Embora defenda a tese de que o catimbó seria uma expressão da magia branca, porque não estaria ligada ao diabólico, à presença de Satã, seus mestres não operavam através e a serviço das forças do diabo, de raízes europeias, não pode deixar de afirmar, em vários momentos, o caráter compósito do catimbó, de como este articula e remaneja diversas crenças, ritos, objetos de culto que têm distintas procedências e origens. Por ser uma expressão religiosa de pessoas muito pobres, o catimbó se utiliza como se fosse de sobras de outros cultos mais sofisticados, simplificando, ao máximo, seus rituais. Ele, em certa passagem, diz com as frases curtas, peremptórias, que são características de seu estilo, frases que sempre parecem enunciar uma verdade definitiva, embora possamos, logo a seguir, no mesmo texto, ver aquela afirmação relativizada ou mesmo negada: "o catimbó é um processo de feitiçaria branca, com cachimbo negro e o fumo indígena”, e completa: “é uma reunião de elementos que vivem noutros ambientes de bruxaria”. ${ }^{65}$ É notória a confusão conceitual, a falta de discussão e elaboração dos conceitos é a grande debilidade da obra de Cascudo. Ele usa indiscriminadamente para definir o catimbó, os conceitos de magia, de feitiçaria, de bruxaria, como se fossem a mesma coisa, não estabelecendo nenhuma distinção entre eles. Mesmo tratando-se de um ritual que também nomeará de sincrético, sem também definir esta noção, talvez por isso mesmo, estes conceitos deveriam ser definidos e ser discutida a pertinência de cada um para definir o catimbó. Em dado momento o autor parece perdido no próprio cipoal de elementos que mobilizou para explicar as práticas do catimbó. À medida que não toma o catimbó como uma expressão própria e contemporânea de religiosidade popular, mas busca estudá-lo como sendo uma reminiscência, como uma persistência de algo do passado e sai em busca destas origens, vai se defrontando com tantas possibilidades que, ao final, o que parece decidir é a sua vontade, o seu desejo de que o catimbó fosse uma expressão da magia branca. A confusão conceitual parece advir da própria singularidade do fenômeno que estuda: culto sempre em 
movimento, em transformação, bricolando elementos de distintas matrizes religiosas e rituais, adaptando-se a cada meio social ou espaço em que se desenrola, tendendo a se adaptar à demanda da clientela, possivelmente, requereria outro aparato conceitual para ser melhor apreendido. Tal como na frase citada mais acima, há vários momentos no livro em que Cascudo tenta sintetizar o que seria o catimbó, definição que se mostrará provisória, pois vai adicionar novos elementos de análise que exigem outra síntese que, em grande medida, desfaz a anterior. Mais adiante, diz ele já com certa hesitação:

Até certo ponto há no Catimbó um sincretismo intenso e contínuo, agora rumando Espiritismo sem doutrina ética. Há a reminiscência da magia branca e européia, a persistência do Bruxo, do Feiticeiro, do Mago onipotente. ${ }^{66}$

O catimbó seria espiritismo sem doutrina ética porque nele tanto era possível fazer trabalhos para as direitas, como para as esquerdas, ou seja, o catimbó atendia o desejo do cliente, sem nenhum travamento ético. Cascudo afirma que, nas conversas que teve com os mestres natalenses, eles disseram que a maior parte das encomendas que recebiam era para fazerem trabalhos para as esquerdas. O trabalho visando o bem alheio, também chamado de fumaça às direitas, constituir-se-ia de tratamentos médicos, remédios e conselhos, orientações benéficas, dádivas de amuletos. Já o trabalho visando fazer o mal a outrem, também chamado de fumaça às esquerdas, seriam vinganças, dificultar negócios, obstar casamentos, enfermar alguém, conquista de mulher casada, despertar paixão sem ser para bom fim. ${ }^{67} \mathrm{O}$ uso do nome fumaça para se referir aos trabalhos se deve à centralidade que o uso do cachimbo tem no ritual do catimbó, objeto ao qual se referiria a própria etimologia da palavra catimbó, que viria de "Catimbau”, que seria um cachimbo pequeno e velho, embora Cascudo levante outras tantas possíveis origens etimológicas para o termo, algumas se referindo a um homem ridículo, outras se referindo a um cheiro ruim, mas a maioria dando como significado mandinga, feitiçaria, sortilégio de origem africana ou espiritismo grosseiro. O estudioso potiguar não parece satisfeito com esta africanização etimológica. Levanta então outra hipótese que se encaminha no sentido de europeizar etimologicamente o vocábulo. Nem mesmo o nome catimbó parece poder ser de origem africana. Vejamos:

Surge, porém, uma dúvida: CATIMBÁO era um termo corrente em Portugal, e já em voga nos albores do século XVIII como comprova o seu registro por Bluteau, com a expressão de 'homem ridículo', que o abona o anexim ou ditado português, sem dúvida, originário de épocas anteriores: 'Dizei ao mestre Catimbáo que se vá embora e dai-lhe com o pau.' Como parece a 
ele, o termo vem de catinbai, nome de uma peça de madeira, corrente entre os carpinteiros e marceneiros franceses. Registrando Morais o termo como chulo, e do Brasil, 'cachimbo pequeno, velho’, como sem dúvida dá aquela mesma definição, ainda era corrente em Portugal, assim o encontrou em voga entre nós. O vocábulo, porém, já não aparece nos modernos léxicos portugueses. Entretanto, fica assim registrada a controvérsia. ${ }^{68}$

Livro que documenta a perseguição policial de que era vítima o catimbó, entre os anos vinte e os cinqüenta do século passado, já que além dos contatos diretos entre Câmara Cascudo e os mestres catimbozeiros, dos quais consegue preciosas informações - algumas conseguidas a custas de pagamento e de apoio jurídico no momento em que estes eram detidos e recambiados para a delegacia de polícia -, da participação e observação direta do intelectual potiguar em sessões e trabalhos, se apóia em notícias de jornais que narravam batidas policiais a casas de culto, em processos-crime, em fotografias feitas na própria delegacia de polícia, algumas registrando os objetos de culto, os mestres do catimbó ao lado de policiais e outras um culto feito para delegado, jornalistas e quem sabe, folclorista ver, além de resultar do conhecimento adquirido pelo etnógrafo potiguar ao receber do próprio Departamento de Segurança Pública, após "batida minuciosa nos arraiais catimbozeiros”, “despojos livrescos que iam ser queimados”. A proximidade que Câmara Cascudo mantinha com a imprensa, já que militava nela desde a sua juventude e com a polícia, seu pai foi chefe de segurança da cidade e militou nos quadros policiais do Estado, parece ter garantido a informações privilegiadas sobre as práticas do catimbó. Estranha, mas não rara cumplicidade entre práticas de repressão e controle e práticas de conhecimento, entre vontade de verdade e vontade de poder e de domínio, quando não de extermínio. Poderíamos dizer que a condição de possibilidade da escrita de Meleagro articula dois diferentes investimentos no sentido de trazer tudo às claras, de acabar com os mistérios, de acabar com as práticas escondidas e obscuras: investimentos da parte da polícia da ordem e investimento por parte da polícia do sentido, da significação: dar a ver e dar a ler estas práticas, estes rituais, seus personagens, seus objetos e matérias de crença, suas convicções. Ambas as ações feitas em nome do benefício à sociedade e à ordem, talvez pensadas em benefício de seus próprios praticantes que poderiam, como aconselhou o médico prefaciador, superar a ignorância, a superstição, sair do estágio da magia, mesmo branca. Polícia da ordem e polícia do sentido que os quer ver civilizados, brancos, europeus. Ações que, se tomarmos como correta a etimologia da palavra catimbó que a refere a um homem ridículo, talvez só consigam revelar a ridicularia que é a de tentar transformar mestiços potiguares em príncipes gregos ou representantes diabóli- 
cos das forças do mal. Meleagro, livro muito importante por tudo o que diz sobre o até então desconhecido e pouco estudado catimbó, mas muito importante também por tudo o que não diz: o silêncio sobre a cumplicidade entre duas ordens de aparelhos de repressão, repressão das práticas e repressão dos discursos, entre a repressão às práticas religiosas e culturais das populações afrodescendentes e a repressão a africanização do sentido destas práticas, cumplicidade baseada num pressuposto comum: ordenar a sociedade, civilizá-la, torná-la culta, erudita e racional é branqueá-la, é europeizá-la, é desafricanizá-la. Clarear, pôr tudo às claras, acabar com o obscuro, com o escuro é acabar com tudo que lembra o negro, que lembra o preto, que lembra a África. Limpeza da cidade e limpeza da memória aí se encontram. Mas a ordem sem rebeldia e resistência, a civilização sem barbárie, a racionalidade sem irracionalidade, a religião sem magia, o intelectual sem superstição, o real sem irreal, o mundo sem deuses, os deuses sem humanos, o claro sem o escuro, o erudito sem a ignorância, o saber sem o desconhecimento, a razão sem a desrazão, sabemos que não passam de mitos, mitos assim como o de Meleagro.

\section{NOTAS}

${ }^{2}$ CASCUDO, Luís da Câmara. Meleagro. 2 ed. Rio de Janeiro: Agir, 1978, p. 15.

${ }^{3}$ Ver, por exemplo: CASCUDO, Luís da Câmara. Geografia dos Mitos Brasileiros. São Paulo: Global, 2002.

${ }^{4}$ FERNANDES, Florestan. O Folclore em Questão. 2 ed. São Paulo: Martins Fontes, 2003.

${ }^{5}$ Ver os estudos recentes dedicados ao autor por Margarida de Souza Neves e Marcos Silva.

${ }^{6}$ VILHENA, Luis Rodolfo. Projeto e Missão: o movimento folclórico brasileiro, 1947-1964. Rio de Janeiro: Fundação Getúlio Vargas/FUNARTE, 1997.

${ }^{7}$ Só dispomos das cartas enviadas por Câmara Cascudo a Gilberto Freyre, disponíveis para consulta na Fundação Casa de Gilberto Freyre, no Recife, as respostas de Freyre para Cascudo estão no Ludovicus - Instituto Câmara Cascudo, em Natal, mas não estão disponíveis para consulta. São uma carta escrita em 1925, duas escritas em 1940, uma de 1943, uma de 1953, uma de 1957, um telegrama de 1960, duas cartas de 1966, uma do ano de 1968, um telegrama de 1970 e um cartão remetido em 1978.

${ }^{8}$ Carta de Câmara Cascudo a Gilberto Freyre, não datada pelo autor, mas identificada por Gilberto Freyre como sendo de 1940.

${ }^{9}$ Ver sobre este tema: SALES NETO, Francisco Firmino. Palavras que Silenciam: Câmara Cascudo e o regionalismo-tradicionalista nordestino. João Pessoa: EDUFPB, 2008.

${ }^{10}$ Ver: CASCUDO, Luís da Câmara. Geografia do Brasil Holandês. Rio de Janeiro: José Olympio, 1956 e História do Rio Grande do Norte. Rio de Janeiro: MEC, 1955. 
${ }^{11}$ MELLO, José Antônio Gonçalves de. Tempo dos Flamengos. 2 ed. São Paulo: Topbooks, 2001.

${ }^{12}$ FREYRE, Gilberto. Casa Grande e Senzala. São Paulo: Global, 2006.

${ }^{13}$ Esta negação ocorre, por exemplo, no livro: CASCUDO, Luís da Câmara. Viajando o Sertão. São Paulo: Global, 2009.

${ }^{14}$ Veja o que ocorre, por exemplo, em: CASCUDO, Luís da Câmara. Made in África. 5 ed. São Paulo: Global, 2001.

${ }^{15}$ CASCUDO, Luís da Câmara. Literatura Oral no Brasil. 2 ed. São Paulo: Global, 2006.

${ }^{16}$ CASCUDO, Luís da Câmara. Made in África, p. 9.

${ }^{17}$ ANDERSON, Benedict. Comunidades Imaginadas. São Paulo: Companhia das Letras, 2008.

${ }^{18}$ CASCUDO, Luís da Câmara. Superstição no Brasil. 5 ed. São Paulo: Global, 2002, p. 47-48.

${ }^{19}$ Ibidem, p. 48.

${ }^{20}$ Chapéu típico de alguns países muçulmanos.

${ }^{21}$ CASCUDO, Luís da Câmara. Superstição no Brasil, p. 49.

${ }^{22}$ Ibidem.

${ }^{23}$ CASCUDO, Luís da Câmara. Meleagro, p. 15.

${ }^{24}$ Idem, Ibidem, p. 23.

${ }^{25}$ Idem, Ibidem, p. 19-20.

${ }^{26}$ Idem, Ibidem, p. 36.

${ }^{27}$ Idem, Ibidem, p. 21.

${ }^{28}$ Idem, Ibidem, p. 19.

${ }^{29}$ Idem, Ibidem, p. 23.

${ }^{30}$ Idem, Ibidem, p. 19

${ }^{31}$ Idem, Ibidem, p. 15.

${ }^{32}$ Idem, Ibidem, p. 19.

${ }^{33}$ Idem, Ibidem, p. 20-21.

${ }^{34}$ Idem, Ibidem, p. 19.

${ }^{35}$ Idem, Ibidem, p. 20.

${ }^{36}$ Idem, Ibidem.

${ }^{37}$ Idem, Ibidem.

${ }^{38}$ Quando em conversa com a velha Liberata, rezadeira pernambucana, ela diz ser o catimbó “coisas de negro”, Cascudo além de lembrar que ela própria era mulata, a corrige dizendo que esses elementos (feitiço com sapo, cabeça de coruja, areia de cemitério) "vinham atravessando tempo e uso, com Europa e Ásia, confusas e amalgamadas”.

${ }^{39}$ CASCUDO, Luís da Câmara. Meleagro, p. 57.

${ }^{40}$ Idem, Ibidem, p. 20.

${ }^{41}$ Idem, Ibidem, p. 89.

${ }^{42}$ Idem, Ibidem, p. 21. 
${ }^{43}$ Idem, Ibidem, p. 89.

${ }^{44}$ Idem, Ibidem, p. 21.

${ }^{45}$ Idem, Ibidem, p. 89.

${ }^{46}$ Idem, Ibidem, p. 21.

${ }^{47}$ Idem, Ibidem, p. 15-16.

${ }^{48}$ Idem, Ibidem, p. 25.

${ }^{49}$ Idem, Ibidem, p. 21.

${ }^{50}$ Idem, Ibidem,, p. 19.

${ }^{51}$ Devemos lembrar que, no momento de redação e publicação deste livro, a Bahia ainda não fazia parte da região Nordeste, mas sim da região Leste. Cascudo parece dar ao catimbó um caráter regional, parece fazer dele uma marca da identidade cultural nordestina em contraposição ao candomblé, que seria uma marca identitária da cultura baiana e a macumba, uma marca de identidade da cultura popular carioca.

${ }^{52}$ CASCUDO, Luís da Câmara. Meleagro, p. 48.

${ }^{53}$ Idem, Ibidem, p. 55.

${ }^{54}$ Idem, Ibidem, p. 55-56.

${ }^{55}$ Idem, Ibidem, p. 31.

${ }^{56}$ Idem, Ibidem, p. 55.

${ }^{57}$ Idem, Ibidem, p. 56-57.

${ }^{58}$ Idem, Ibidem, p. 22.

${ }^{59}$ Idem, Ibidem, p. 87.

${ }^{60}$ MELLO, Antônio da Silva. Prefácio. In: CASCUDO, Luís da Câmara. Meleagro, p. 12.

${ }^{61}$ CASCUDO, Luís da Câmara. Meleagro, p. 22.

${ }^{62}$ Idem, Ibidem, p. 23.

${ }^{63}$ Idem, Ibidem, p. 25.

${ }^{64}$ Idem, Ibidem, p. 26.

${ }^{65}$ Idem, Ibidem, p. 27.

${ }^{66}$ Idem, Ibidem, p. 41.

${ }^{67}$ Idem, Ibidem, p. 31-32. 